\title{
Alkaline Reactivity of Arsenical Natrojarosite
}

\author{
Iván A. Reyes, Francisco Patiño,* Isauro Rivera, Mizraím U. Flores, \\ Martín Reyes and Juan Hernández.
}

\author{
Centro de investigaciones en Materiales y Metalurgia, Universidad Autónoma del Estado de Hidalgo, \\ Carretera Pachuca-Tulancingo Km 4.5, CP 42081, Pachuca, Hidalgo, México
}

\begin{abstract}
Jarosites são compostos que podem sofrer substituições com vários elementos de importância ambiental (tais como $\mathrm{As}^{5+}$ ) durante a precipitação. Arsênico integrado na estrutura poderia influenciar a solubilidade da jarosita, potencialmente estabilizando a estrutura em uma ampla gama de condições que são toleradas pela jarosita pura. A reatividade álcali é caracterizada pela remoção de íons sulfato e sódio da rede e a formação de um gel composto de hidróxido de ferro com arseniato adsorvido. As curvas de decomposição mostram um período de indução seguida por um período de conversão. O período de indução é independente do tamanho das partículas e decresce exponencialmente com o aumento da temperatura. O período de conversão é caracterizado pela criação de um halo de hidróxidos em torno de um núcleo de natrojarosita arsênica não reagido. Dados cinéticos são consistentes com o controle químico do processo. A expressão obtida em meio $\mathrm{NaOH}$ para as concentrações de $\left[\mathrm{OH}^{-}\right]$que vão desde $3,84 \times 10^{-3}$ para $1,08 \times 10^{-1} \mathrm{~mol} \mathrm{~L}^{-1}$ é: $\mathrm{r}_{0} / \overline{\mathrm{v}}\left[1-(1-\mathrm{x})^{1 / 3}\right]=3,11 \times 10^{9} \exp (-57,110 / \mathrm{RT})\left[\mathrm{OH}^{-}\right]^{0.7}$ t. A expressão em meio $\mathrm{Ca}(\mathrm{OH})_{2}$ para as concentrações de $\left[\mathrm{OH}^{-}\right]$que vão desde $2,21 \times 10^{-2}$ para $6,98 \times 10^{-2} \mathrm{~mol} \mathrm{~L}^{-1}$ é: $\mathrm{r}_{0} / \overline{\mathrm{v}}\left[1-(1-\mathrm{x})^{1 / 3}\right]=9,22 \times 10^{11} \exp (-48,610 / \mathrm{RT})\left[\mathrm{OH}^{-}\right]^{1.51} \mathrm{t}$.
\end{abstract}

Jarosites are compounds that can undergo substitutions with several elements of environmental importance (such as $\mathrm{As}^{5+}$ ) during precipitation. Arsenic integrated in the structure could influence the solubility of the jarosite, potentially stabilizing the structure under a wide range of conditions that are tolerated by pure jarosite. Alkaline reactivity is characterized by the removal of sulfate and sodium ions from the lattice and by the formation of a gel consisting of iron hydroxides with adsorbed arsenate. The decomposition curves show an induction period, followed by a conversion period. The induction period is independent from the particle size and decreases exponentially as the temperature increases. The conversion period is characterized by the formation of a hydroxide halo around an unreacted arsenical natrojarosite core. The kinetic data are consistent with the chemical control of the process. The expression obtained in $\mathrm{NaOH}$ medium for $\left[\mathrm{OH}^{-}\right]$concentrations ranging from $3.84 \times 10^{-3}$ to $1.08 \times 10^{-1} \mathrm{~mol} \mathrm{~L}^{-1}$ is the following: $\mathrm{r}_{0} / \overline{\mathrm{v}}\left[1-(1-\mathrm{x})^{1 / 3}\right]=3.11 \times 10^{9} \exp (-57.110 / \mathrm{RT})\left[\mathrm{OH}^{-}\right]^{0.7} \mathrm{t}$. The expression in $\mathrm{Ca}(\mathrm{OH})_{2}$ medium for $\left[\mathrm{OH}^{-}\right]$concentrations ranging from $2.21 \times 10^{-2}$ to $6.98 \times 10^{-2} \mathrm{~mol} \mathrm{~L}^{-1}$ is the following: $\mathrm{r}_{0} / \overline{\mathrm{v}}\left[1-(1-\mathrm{x})^{1 / 3}\right]=9.22 \times 10^{11} \exp (-48.610 / \mathrm{RT})\left[\mathrm{OH}^{-}\right]^{1.51} \mathrm{t}$.

Keywords: reactivity, arsenical natrojarosite, kinetics, arsenate, decomposition, amorphous

\section{Introduction}

The arsenic pollution of water is considered a problem of catastrophic proportions. Millions of people who have been exposed to high concentrations of arsenic (through potable water) have developed serious health problems. Countries such as Argentina, Chile, Bangladesh, India, Mexico, Taiwan, Thailand, United States and Vietnam have reported the presence of arsenic in ground waters at

*e-mail: franpac@infosel.net.mx alarming levels. ${ }^{1}$ The high toxicity of this element makes necessary to apply a maximum admissible concentrations in potable water. The WHO (World Health Organization) establishes, through its guidelines, that the maximum admissible content of arsenic in potable water should be reduced from 0.05 to $0.01 \mathrm{mg} \mathrm{L}^{-1}$. As a consequence, Germany reduced its limit to $0.01 \mathrm{mg} \mathrm{L}^{-1}$ in 1996, Australia from 0.050 to $0.007 \mathrm{mg} \mathrm{L}^{-1}$, the current standard in France is $0.015 \mathrm{mg} \mathrm{L}^{-1}$, in Vietnam $0.05 \mathrm{mg} \mathrm{L}^{-1}$. $^{2}$ In Mexico, 
the limit was $0.05 \mathrm{mg} \mathrm{L}^{-1}$ in $1994,{ }^{3}$ and was reduced to $0.025 \mathrm{mg} \mathrm{L}^{-1}$ in $2005 .^{4}$

Thus, the use of innovative techniques for the elimination of arsenic is an important subject. Arsenic cannot be easily destroyed, and can only be changed into different forms or transformed into soluble compounds in combination with other elements, such as iron. Several impurities, like lead, iron and selenium, are often mixed with the arsenic wastes, becoming more difficult the removal. Treatment technologies are available and most of them have been developed for the removal of arsenic at an industrial scale in water treatment plants. Some of the available methods include the removal of arsenic by precipitation/ co-precipitation and filtration, removal by adsorption in natural or artificial adsorbents, water softening with lime, ionic interchange in activated alumina, processes with membranes and oxidation-reduction reactions. ${ }^{5,6}$

Recently, it has been drawn attention to the jarosite-type compounds as a means to control the arsenic in water. The jarosites with general formula $\mathrm{AFe}_{3}(\mathrm{SO} 4)_{2}(\mathrm{OH})_{6}$, where A is predominantly $\mathrm{K}, \mathrm{Na}, \mathrm{NH}_{4}$ or $\mathrm{H}_{3} \mathrm{O}$, are compounds that can suffer substitutions with considerable amounts of elements of environmental importance during precipitation, such as $\mathrm{As}^{5+}, \mathrm{Cr}^{3+}, \mathrm{Pb}^{2+}, \mathrm{Cd}^{2+}$ or $\mathrm{Hg}^{2+}$. This is due to the different coordination environments in the position of the cations or to the substitution of $\mathrm{SO}_{4}^{2-}$ by oxoanions formed by these elements $\left(\mathrm{AsO}_{4}^{3-}, \mathrm{CrO}_{4}^{2-}\right)$. Although $\mathrm{As}^{3+}$ is not precipitated with the jarosite, the $\mathrm{As}^{5+}$ is widely removed with the precipitation, which could be useful as a strategy for controlling the arsenic. The manner in which the arsenic is incorporated into the jarosite can influence the mobility and bioavailability of arsenic in controlled or natural environments. Arsenic incorporated in the structure could influence the solubility of jarosite, potentially stabilizing the structure under a wide range of conditions that are tolerated by the pure jarosite. ${ }^{7}$ For instance: it will be difficult for the arsenic to be solubilized under acidic conditions, which are necessary for the precipitation of the jarosites. But if the arsenic is present as a separate phase, like scorodite or a similar phase, its chemical behavior will be different from that of the jarosite, and the dissolution of the arsenic will be able to occur under acidic conditions, which are common in the jarosite deposits. ${ }^{8}$

Therefore, jarosites containing arsenic have an environmental importance, not only as a means to control the As in water, but it is also well known that the hydrometallurgical industries, mainly the zinc industry, use jarosite precipitation as a means to control iron, sulfates and alkaline metals among others. This generates a great amount of potentially dangerous residuals, ${ }^{9}$ because after their dissolution or decomposition, the arsenic might be released again in a form which is bioavailable for the ecosystems. There are few works on the dissolution and stability of such compounds, ${ }^{10-14}$ making the data insufficient for evaluating the real environmental risk caused by the improper disposal of the generated precipitates.

The objective of this article is to present a detailed kinetic study on the alkaline reactivity (in $\mathrm{NaOH}$ and $\mathrm{CaO}$ media) of the sodium jarosite with arsenic in order to provide information regarding the stability of these compounds in these kind of media, because, as previously mentioned, jarosites are very stable in acidic media. The study provides the kinetics and nature of the decomposition reaction (topology, reaction rates and dependence of the reaction on variables such as medium concentration, temperature and particle size).

\section{Experimental}

\section{Materials}

Arsenical natrojarosite was used for the reactivity study. The synthesis method was selected from the works published by Dutrizac et al. ${ }^{15}$ The synthesis was carried out by precipitation in a glass kettle with mechanical stirring. The synthesis conditions were the following: $0.3 \mathrm{~mol} \mathrm{~L}^{-1} \mathrm{Fe}_{2}\left(\mathrm{SO}_{4}\right)_{3}, 0.01 \mathrm{~mol} \mathrm{~L}^{-1} \mathrm{H}_{2} \mathrm{SO}_{4}, 0.2 \mathrm{~mol} \mathrm{~L}^{-1}$ $\mathrm{Na}_{2} \mathrm{SO}_{4}, 0.027 \mathrm{~mol} \mathrm{~L}^{-1} \mathrm{Na}_{2} \mathrm{HAsO}_{4} \cdot 7 \mathrm{H}_{2} \mathrm{O}$, all in AR reagent grade, J. T. Baker, in a total volume of $1 \mathrm{~L}$ at $94.5^{\circ} \mathrm{C}$ for $24 \mathrm{~h}$, and $56 \mathrm{~g}$ of arsenical jarosite were obtained. The resulting product was characterized by chemical analysis (gravimetric and volumetric), X-ray diffraction (XRD) analysis using a Siemens D-500, scanning electron microscopy (SEM) JEOL model JSM-5900LV equipped with a detector energy X-ray backscatter (EDS) Oxford, and granulometric analysis. The characterization confirms a simple phase product. The resulting chemical composition $\left(4.1 \% \mathrm{Na}, 28.8 \% \mathrm{Fe}, 1.0 \% \mathrm{AsO}_{4}, 41.8 \% \mathrm{SO}_{4}, 24.2 \%\right.$ $\mathrm{H}_{3} \mathrm{O}+\mathrm{OH}+\mathrm{H}_{2} \mathrm{O}$ ) corresponds to a solid solution of hydrated arsenical natrojarosite-hydronium jarosite with the following approximate formula:

$\left[\mathrm{Na}_{0.87}\left(\mathrm{H}_{3} \mathrm{O}\right)_{0.13}\right] \mathrm{Fe}_{2.50}\left[\left(\mathrm{SO}_{4}\right)_{1.95}\left(\mathrm{AsO}_{4}\right)_{0.05}\right]\left[(\mathrm{OH})_{4.45}\left(\mathrm{H}_{2} \mathrm{O}\right)_{1.55}\right]$

Dutrizac et al. ${ }^{15}$ obtained similar products under similar conditions. The density measurement yielded a value of $2.83 \mathrm{~g} \mathrm{~cm}^{-3}$.

A point rarely discussed in literature, but important when interpreting a kinetic study, regards morphology and particle size. The synthesis of the arsenical natrojarosite under the described conditions allows the formation of spheroidal aggregates (Figure 1, SEM image), which are 


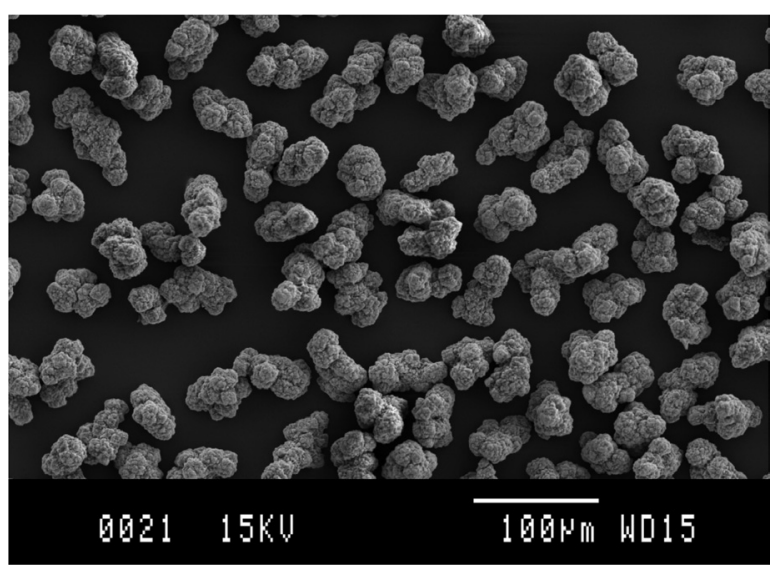

Figure 1. Particle size image $(36-40 \mu \mathrm{m})$ obtained for arsenical natrojarosite by SEM technique.

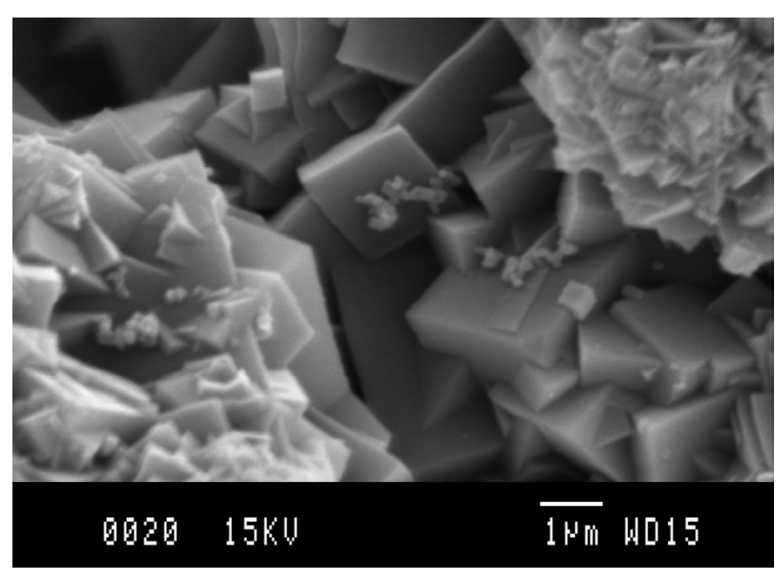

Figure 2. Detail of a spherical particle constituted by rhombohedral crystals obtained for arsenical natrojarosite by SEM technique.

made of rhombohedral crystals measuring from 2 to $5 \mu \mathrm{m}$ (Figure 2, SEM image under higher magnification), these are soundly soldered in a compact texture. For the kinetic study, we used particle sizes of $38 \pm 2 \mu \mathrm{m}$, which were obtained by wet sieving, except for the study on particle size effect.

\section{Experimental procedure}

The experiment for the alkaline decomposition was carried out in a conventional thermostated glass kettle with magnetic stirring. The $\mathrm{pH}$ of the solution was constantly measured, and the experiments were designed so that the reactant concentrations would be constantly adjusted.

For studying the decomposition in $\mathrm{NaOH}$ and $\mathrm{Ca}(\mathrm{OH})_{2}$ media, both in AR reagent grade, J. T. Baker, $0.2 \mathrm{~g}$ of arsenical jarosite was used in a volume of $500 \mathrm{~mL}$, respectively. In both media, the $\mathrm{pH}$ was kept constant by adding small amounts of $\mathrm{NaOH}$ or $\mathrm{Ca}(\mathrm{OH})_{2}$ during the experiment. The $\mathrm{OH}^{-}$concentration was calculated on the base of the $\mathrm{pH}$ of the solution, and the ionic constant of the water was calculated on the base of the working temperature. ${ }^{16}$

As noted previously, the alkaline decomposition process is characterized by the release of sulfate and sodium ions from the lattice and their rapid diffusion towards the solution. In $\mathrm{NaOH}$ medium, the reaction progress was followed by taking solution samples $(5 \mathrm{~mL})$ that were analyzed for sulfate by inductively coupled plasma spectroscopy (ICP), Perkin Elmer-Optima 3000XL. In $\mathrm{Ca}(\mathrm{OH})_{2}$ medium, a similar procedure was applied: the reaction progress was followed by sodium analysis using atomic absorption spectrometry (AAS), Perkin Elmer-Analyst 200. It is important to note that, during the alkaline decomposition process, arsenic was not detected in the samples analyzed by AAS and ICP. For these analyses, standards with an identical matrix were used. The alterations due to the sampling and reagent addition were corrected by mass balance. According to the previously stated, several experiments were carried out in order to observe the evolution of the solids at different conversion values. These solids were characterized by chemical analysis, $\mathrm{X}$-ray diffraction (XRD), scanning electron microscopy (SEM) and energy-dispersive X-ray analysis (EDS).

\section{Results and Discussion}

Decomposition of arsenical natrojarosite in $\mathrm{NaOH}$ and $\mathrm{Ca}(\mathrm{OH})_{2}$ media

\section{Stoichiometry}

In order to study the stoichiometry of the reaction, samples of arsenical natrojarosite were treated for long periods with $\mathrm{NaOH}$ and $\mathrm{Ca}(\mathrm{OH})_{2}$. Then, the sulfate and sodium in the solution were analyzed, and the residues were characterized by XRD and EDS. The results of the evolution of the reacted fraction of sulfates and sodium during decomposition are shown in Figure 3.

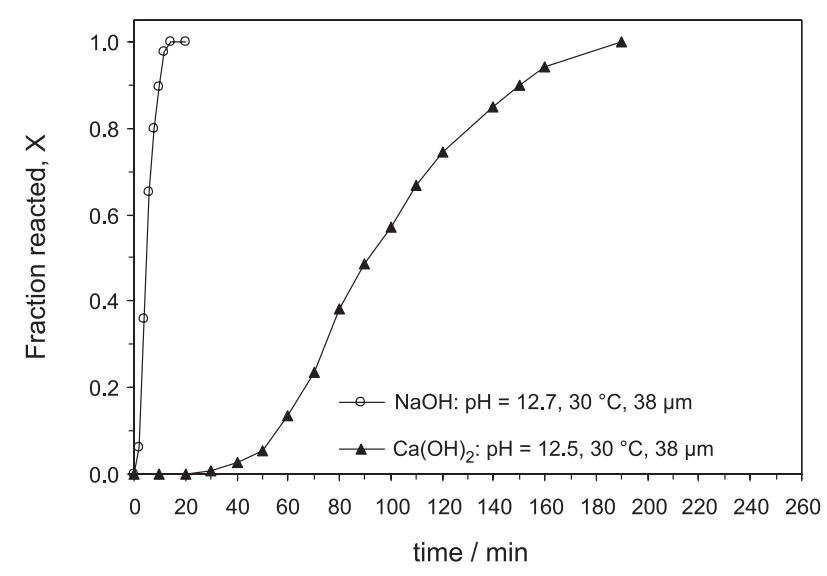

Figure 3. Examples of the decomposition curves of the arsenical natrojarosite in alkaline media. 
Figure 4 shows the diffractograms of the residues corresponding to the data in Figure 3, including periods after the total decomposition (the remaining reflection intensity in $2 \theta=29^{\circ}$ is caused by the formation of $\mathrm{CaCO}_{3}$, because the decomposition was carried out in $\mathrm{CaO}$, as observed in Figure $4 \mathrm{~b}$ ). The solid residues are amorphous, and do not evolve into crystal phases under the conditions of alkaline decomposition herein studied (as observed in Figure 4).
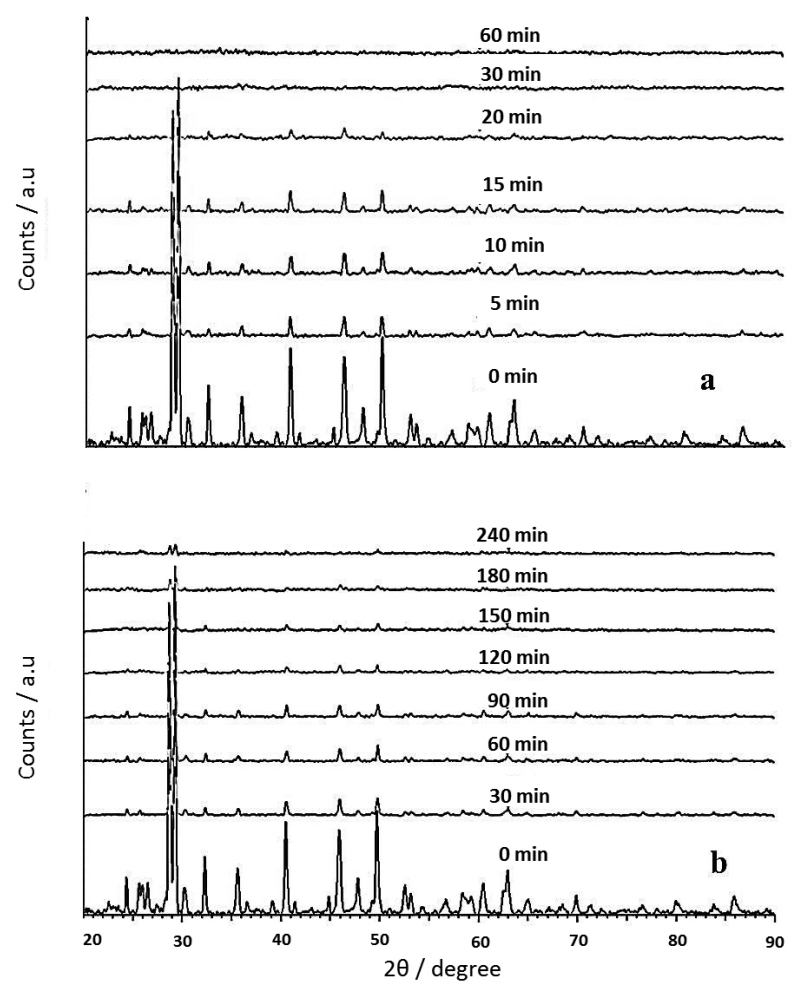

Figure 4. Diffractograms of the reaction products at different times: (a) $\mathrm{NaOH}$ and (b) $\mathrm{Ca}(\mathrm{OH})_{2}$ media.

According to the previous descriptions, it can be noted that the alkaline decomposition starts with an induction period $\left(\mathrm{t}_{\text {ind }}\right)$, during which the external appearance (color, morphology etc.) of the arsenical natrojarosite remains without changes, and only traces of sulfate and sodium ions were found in solution. In a similar way, the diffractograms of the solids during this period were identical in position and line intensity with respect to those of the original arsenical natrojarosite. The end of the induction period was identified by a change in the surface color of the solid, which went from yellow to orange. SEM analysis indicated the formation of a reaction front. The concentration of sulfates and sodium progressively increases, while simultaneously, the reflection intensities of the arsenical natrojarosite decrease until disappearing. This occurs when the concentrations of sulfates and sodium are stabilized, indicating that the reaction has finished. According to the previously stated, the stoichiometry of the process can be expressed according to the following reaction:

$\left[\mathrm{Na}_{0.87}\left(\mathrm{H}_{3} \mathrm{O}\right)_{0.13}\right] \mathrm{Fe}_{2.50}\left[\left(\mathrm{SO}_{4}\right)_{1.95}\left(\mathrm{AsO}_{4}\right)_{0.05}\right]\left[(\mathrm{OH})_{4.45}\left(\mathrm{H}_{2} \mathrm{O}\right)_{1.55}\right]_{(\mathrm{S})}+$ $3.18 \mathrm{OH}^{-}{ }_{\text {aq) }} \rightarrow 0.87 \mathrm{Na}^{+}{ }_{\text {(aq) }}+1.95 \mathrm{SO}_{4}^{2-}{ }_{(\mathrm{aq})}+2.5 \mathrm{Fe}(\mathrm{OH})_{3}$ $0.05 \mathrm{AsO}_{4}^{3-}(\mathrm{gel})+1.81 \mathrm{H}_{2} \mathrm{O}_{(\mathrm{l})}$

\section{Decomposition curves}

The first characteristic of the kinetic curves is the presence of an induction period that increases as the temperature drops, and it is generally increased as the $\left[\mathrm{OH}^{-}\right]$ decreases. The solids were analyzed by EDS during this period. There are no morphological changes or formation of any detectable solid layer at practical resolution levels of the EDS technique ( $c a .0 .1 \mu \mathrm{m})$. This leads to the conclusion that it is a surface phenomenon occurring at a level of molecular thickness, which is related to adsorption processes (and whose detailed mechanism needs to be studied by means of techniques that were unavailable for this work). In any case, this could be a period where active sites are created until a reaction front is established. It was proved that surface attack of the arsenical jarosite with $\mathrm{HCl}$ (a way to create surface defects or to remove submicron films) reduces the induction period. However, since it is a common phenomenon in the decomposition of this type of compounds, the induction period has not been eliminated in this research work, and its dependence on $\mathrm{OH}^{-}$concentration, temperature and particle size have been determined.

Furthermore, there are semi-empirical expressions to describe the autocatalytic kinetic processes, ${ }^{17}$ as well as processes related to nucleation and growth. ${ }^{18}$ These relations yield S-type kinetic curves, and they could be used to describe the total decomposition curves found in this study. However, these models were deduced by considering the constant increases in the reaction interface, which in this case did not happen. The solids examination by EDS after the induction period indicates the presence of a reaction front with an unreacted arsenical natrojarosite core and a gel halo of iron hydroxide with adsorbed arsenate. Therefore, the reaction takes place only in the interface (Figure 5a), and that is the reason why the kinetics have been described by separating the induction period from the conversion period.

It was observed, then, that the ion diffusion through the decomposition gel was quick (Figure $5 b$ ).

The model selected for the conversion period was the model of decreasing core and chemical control, which, for particles, takes the following expression: ${ }^{19,20}$

$$
\begin{aligned}
& 1-(1-\mathrm{x})^{1 / 3}=\mathrm{K}_{\text {exp }} \mathrm{t} \\
& \mathrm{K}_{\text {exp }}=\overline{\mathrm{v}} \mathrm{K}_{\mathrm{q}} \mathrm{C}_{\mathrm{A}}{ }^{\mathrm{n}} / \mathrm{r}_{0}
\end{aligned}
$$


(a)
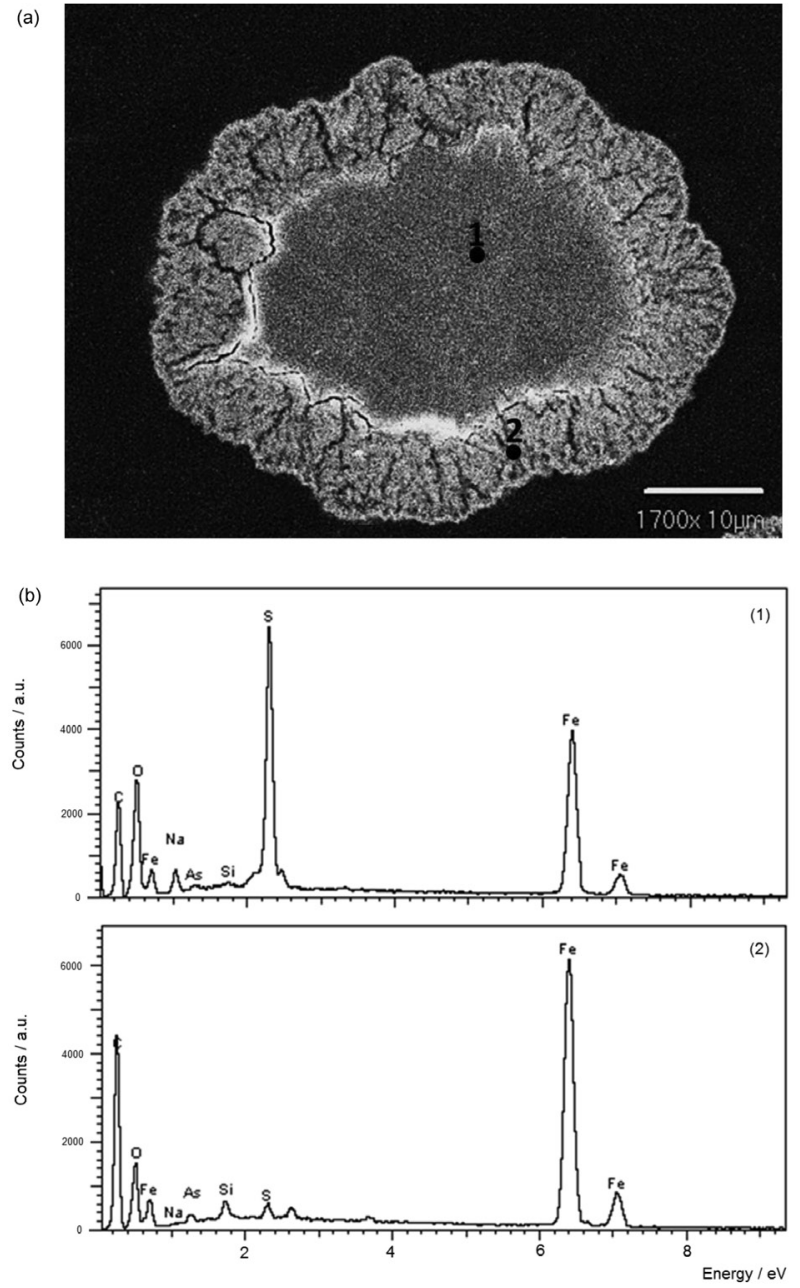

Figure 5. (a) SEM micrograph of partially reacted particles of arsenical natrojarosite $\left(\mathrm{NaOH}, \mathrm{pH} 12.73,30^{\circ} \mathrm{C}\right)$ and (b) EDS analysis corresponding to points 1 and 2 of Figure $5 \mathrm{a}$.

where $\mathrm{x}=$ reacted fraction, $\mathrm{K}_{\mathrm{q}}=$ chemical constant, $\mathrm{C}_{\mathrm{A}}=$ reactant concentration, $\overline{\mathrm{v}}=$ molar volume of the solid, $\mathrm{r}_{0}=$ initial radius and $\mathrm{n}=$ reaction order.

The data are consistent with the model (Figure 6). The values of the rate experimental constants $\mathrm{K}_{\exp }$ were obtained by linear regression of equation 2 . The values of the induction times $\left(\mathrm{t}_{\text {ind }}\right)$ were obtained from the intersections of the regression straight line with the time axis.

\section{Dependence of the induction period}

In $\mathrm{NaOH}$ medium, $1 / \mathrm{t}_{\text {ind }}$ was proportional to $\left[\mathrm{OH}^{-}\right]$ (Figure 7). In $\mathrm{Ca}(\mathrm{OH})_{2}$ medium, almost identical values were found with $\left[\mathrm{OH}^{-}\right]$of up to $5.68 \times 10^{-3} \mathrm{~mol} \mathrm{~L}^{-1}$ approximately. At higher $\mathrm{OH}^{-}$concentrations, $t_{\text {ind }}$ became independent from that value. In spite of these differences, the temperature effect was exponential in both media. Figure 8 is a plot of $\ln \left(1 / \mathrm{t}_{\text {ind }}\right) v s$. $1 / \mathrm{T}$. The values of the dependence of energy in $\mathrm{NaOH}$ medium were of $120.4 \mathrm{~kJ} \mathrm{~mol}^{-1}$, and $79.4 \mathrm{~kJ} \mathrm{~mol}^{-1}$ in $\mathrm{Ca}(\mathrm{OH})_{2}$ medium.

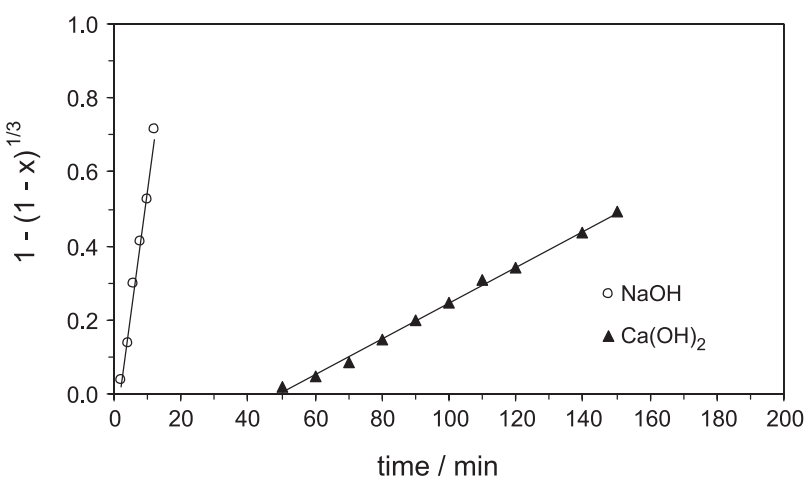

Figure 6. Plot lines according to the data of the model of decreasing core and chemical control.

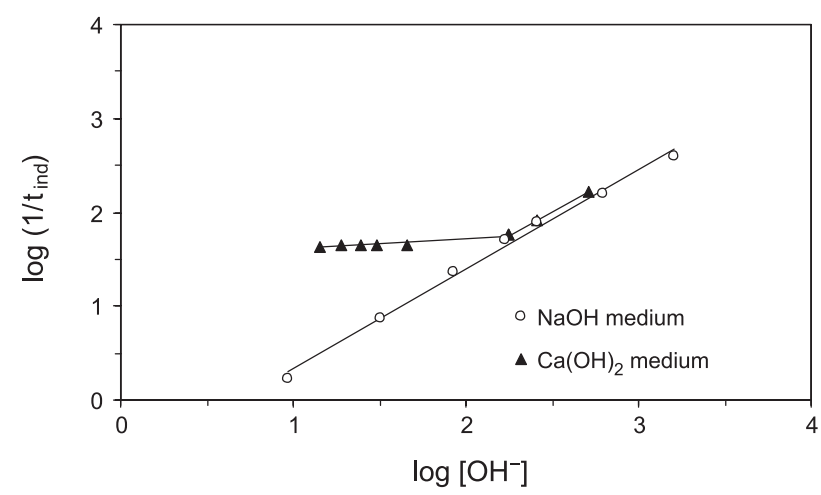

Figure 7. The $\left[\mathrm{OH}^{-}\right]$effect on the induction period $\left(\mathrm{t}_{\text {ind }}\right)$ in $\mathrm{NaOH}$ and $\mathrm{Ca}(\mathrm{OH})_{2}$ media $\left(30^{\circ} \mathrm{C}\right)$.

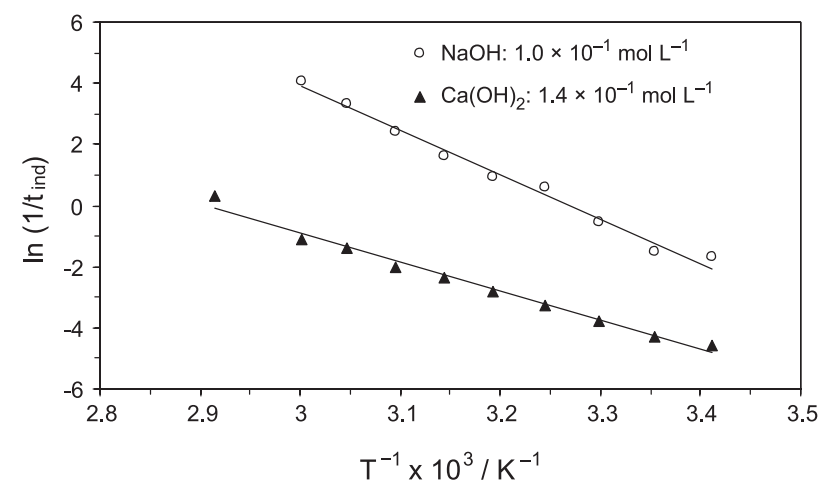

Figure 8. The dependence of the induction period $\left(\mathrm{t}_{\text {ind }}\right)$ on the temperature $(\mathrm{T})$ in $\mathrm{NaOH}$ and $\mathrm{Ca}(\mathrm{OH})_{2}$ media.

Besides, in both media, $t_{\text {ind }}$ is independent from the particle size (Figure 9), which confirms that the activation process is a phenomenon occurring at levels of molecular thickness, involving only the initial surface.

\section{Dependence of the conversion period}

Figure 10 shows the particle size effect on the decomposition rate of the arsenical natrojarosite. A plot of the rate experimental constants (determined at constant temperature and concentration) $v s$. the inverse of the diameter was linear, and passed through the origin. This is consistent with the spherical particle model with decreasing 


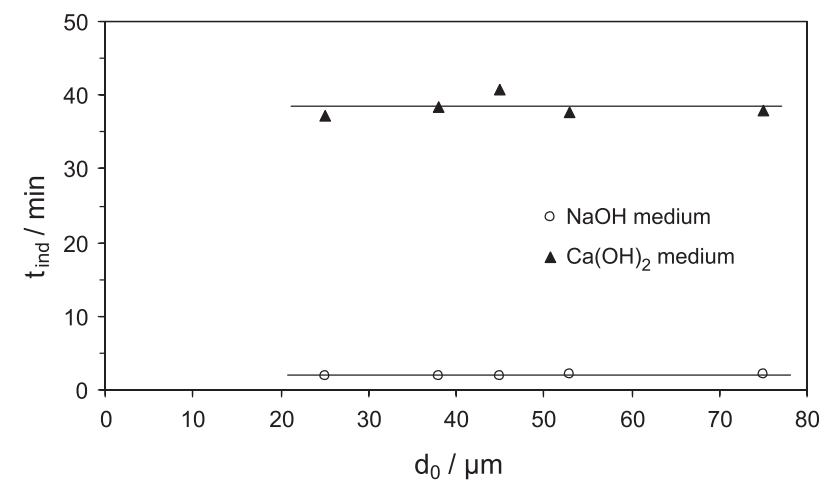

Figure 9. The particle size $\left(d_{0}\right)$ effect on the induction period $\left(t_{\text {ind }}\right)$ in $\mathrm{NaOH}$ and $\mathrm{Ca}(\mathrm{OH})_{2}$ media.

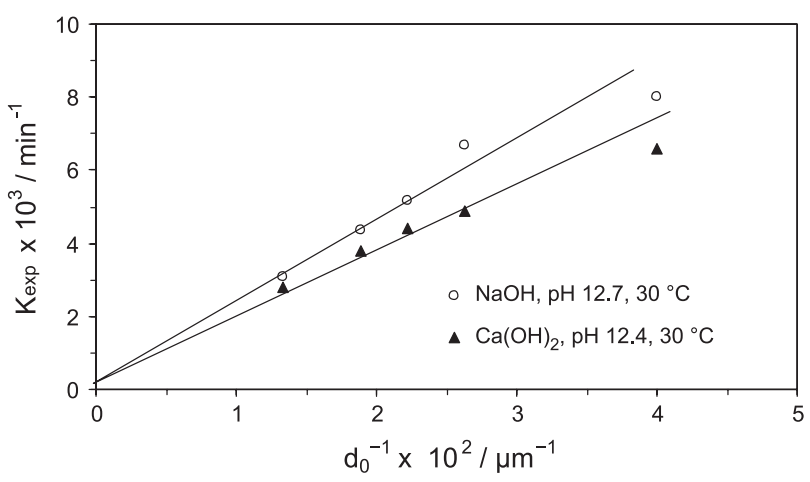

Figure 10. Plot of the rate constants $\left(\mathrm{K}_{\mathrm{exp}}\right) v s$. the inverse of the particle initial diameter $\left(\mathrm{d}_{0}^{-1}\right)\left(30^{\circ} \mathrm{C}\right)$ in $\mathrm{NaOH}$ and $\mathrm{Ca}(\mathrm{OH})_{2}$ media.

core and chemical control (equation 2). In addition, these results rule out the control by transport through the layer of the product. Therefore, in this case, the rate constants are inversely proportional to the square of the initial diameter $\left(\mathrm{d}_{0}\right) \cdot{ }^{20}$

In the decomposition process in $\mathrm{NaOH}$ medium for $\left[\mathrm{OH}^{-}\right]$of $3.84 \times 10^{-3}$ to $1.08 \times 10^{-1} \mathrm{~mol} \mathrm{~L}^{-1}$, the reaction order was 0.7 , and for $\left[\mathrm{OH}^{-}\right]$lower than $3.84 \times 10^{-3}$, the reaction order was 0 (Figure 11). In the decomposition process in $\mathrm{Ca}(\mathrm{OH})_{2}$ medium for $\left[\mathrm{OH}^{-}\right]$of $2.21 \times 10^{-2}$ to $6.98 \times 10^{-2} \mathrm{~mol} \mathrm{~L}^{-1}$, the reaction order was 1.51 , and for $\left[\mathrm{OH}^{-}\right]$lower than $2.21 \times 10^{-2}$, the reaction order was 0

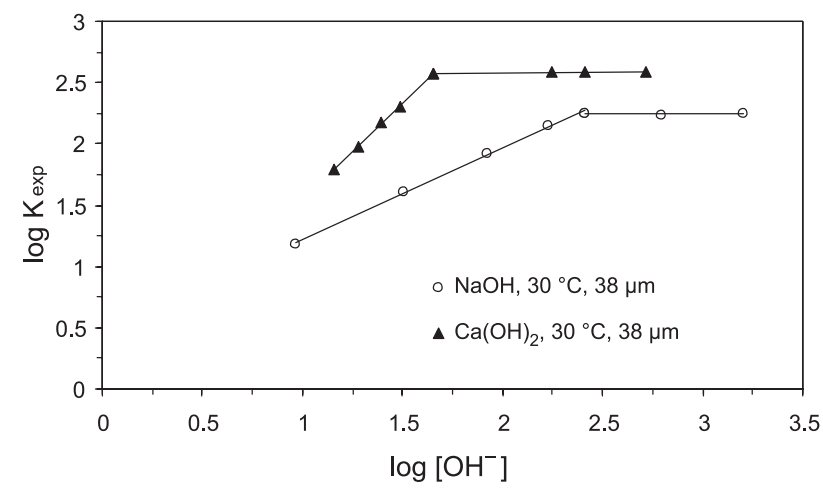

Figure 11. The $\left[\mathrm{OH}^{-}\right]$effect on the rate constants $\left(\mathrm{K}_{\text {exp }}\right)$ in $\mathrm{NaOH}$ and $\mathrm{Ca}(\mathrm{OH})_{2}$ media $\left(\mathrm{d}_{0} 38 \mu \mathrm{m}\right.$ and $\left.30^{\circ} \mathrm{C}\right)$.
(Figure 11). This kind of dependence is related to the chemical control; therefore, it is incompatible with the control by diffusion of reactants through the layer of the product. $^{20,21}$

The temperature effect was studied in both $\mathrm{NaOH}$ and $\mathrm{Ca}(\mathrm{OH})_{2}$ media. However, since the ionization constant of water varies considerably with temperature,${ }^{16}$ the Arrhenius plot (Figure 12) was obtained by using $\ln \left(\mathrm{K}_{\text {exp }} /\left[\mathrm{OH}^{-}\right]^{\mathrm{n}}\right)$ in order to eliminate the $\left[\mathrm{OH}^{-}\right]$effect on the temperature dependence.

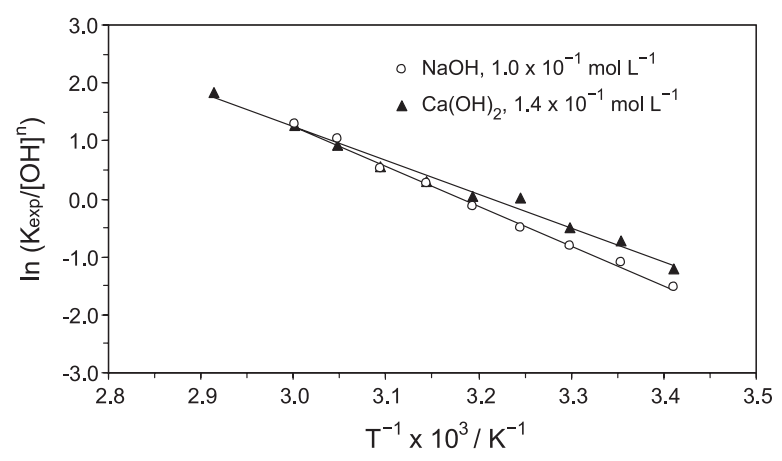

Figure 12. Temperature effect on the progressive conversion period in $\mathrm{NaOH}$ medium $\left(1.0 \times 10^{-2} \mathrm{~mol} \mathrm{~L}^{-1}\right)$ and $\mathrm{Ca}(\mathrm{OH})_{2}$ medium $\left(1.4 \times 10^{-2} \mathrm{~mol} \mathrm{~L}^{-1}\right)\left(\mathrm{d}_{0} 38 \mu \mathrm{m}\right)$, where $\mathrm{n}$ is the fractional order, in $\mathrm{NaOH}$ medium $\mathrm{n}=0.7$, in $\mathrm{Ca}(\mathrm{OH})_{2}$ medium $\mathrm{n}=1.51$.

Temperature effect indicates an activation energy of $57.1 \mathrm{~kJ} \mathrm{~mol}^{-1}$ in $\mathrm{NaOH}$ medium (Figure 12). The activation energy obtained in $\mathrm{Ca}(\mathrm{OH})_{2}$ medium was of $48.6 \mathrm{~kJ} \mathrm{~mol}^{-1}$ (Figure 12). The activation energy values are within the limits of chemical control. The kinetic expression of the arsenical natrojarosite decomposition in $\mathrm{NaOH}$ medium for $\left[\mathrm{OH}^{-}\right]$concentrations ranging from $3.84 \times 10^{-3}$ to $1.08 \times 10^{-1} \mathrm{~mol} \mathrm{~L}^{-1}$ can be written (for the conversion period) as follows:

$\mathrm{r}_{0} / \overline{\mathrm{v}}\left[1-(1-\mathrm{x})^{1 / 3}\right]=3.14 \times 10^{9} \exp (-57.110 / \mathrm{RT})\left[\mathrm{OH}^{-}\right]^{0.7 \mathrm{t}}$

For $\left[\mathrm{OH}^{-}\right]$concentrations below $3.84 \times 10^{-3} \mathrm{~mol} \mathrm{~L}^{-1}$ it can be written as follows:

$\mathrm{r}_{0} / \overline{\mathrm{v}}\left[1-(1-\mathrm{x})^{1 / 3}\right]=3.14 \times 10^{9} \exp (-57.110 / \mathrm{RT})\left[\mathrm{OH}^{-}\right]^{0} \mathrm{t}$

The kinetic expression of the decomposition of the arsenical natrojarosite in $\mathrm{Ca}(\mathrm{OH})_{2}$ medium for $\left[\mathrm{OH}^{-}\right]$ concentrations ranging from $2.21 \times 10^{-2}$ to $6.98 \times 10^{-2} \mathrm{~mol} \mathrm{~L}^{-1}$ can be the following (for the conversion period):

$\mathrm{r}_{0} / \overline{\mathrm{v}}\left[1-(1-\mathrm{x})^{1 / 3}\right]=1.4 \times 10^{8} \exp (-48.610 / \mathrm{RT})\left[\mathrm{OH}^{-}\right]^{1.51} \mathrm{t}$

For $\left[\mathrm{OH}^{-}\right]$concentrations below $2.21 \times 10^{-2} \mathrm{~mol} \mathrm{~L}^{-1}$, it can be written as follows: 
Table 1. Rate experimental constant values of natrojarosites with and without arsenic

\begin{tabular}{lc}
\hline Jarosite type / formula & $\mathrm{NaOH}$ \\
\hline Arsenical natrojarosite: ${ }^{\text {a }}$ & $\mathrm{Ka}(\mathrm{OH})_{2}$ \\
{$\left[\mathrm{Na}_{0.87}\left(\mathrm{H}_{3} \mathrm{O}\right)_{0.13}\right] \mathrm{Fe}_{2.50}\left[\left(\mathrm{SO}_{4}\right)_{1.95}\left(\mathrm{AsO}_{4}\right)_{0.05}\right]\left[(\mathrm{OH})_{4.45}\left(\mathrm{H}_{2} \mathrm{O}\right)_{1.55}\right]$} & 0.180 \\
Natrojarosite: $^{\text {b }}$ & 0.23 \\
{$\left[\mathrm{Na}_{0.675} \mathrm{Ag}_{0.005} \mathrm{H}_{3} \mathrm{O}_{0.32}\right] \mathrm{Fe}_{2.70}\left(\mathrm{SO}_{4}\right)_{2}(\mathrm{OH})_{5.10}$} & 0.182 \\
\hline
\end{tabular}

aThis work; ${ }^{\mathrm{b}}$ Patiño et al. ${ }^{22}$

$\mathrm{r}_{0} / \overline{\mathrm{v}}\left[1-(1-\mathrm{x})^{1 / 3}\right]=1.4 \times 10^{8} \exp (-48.610 / \mathrm{RT})\left[\mathrm{OH}^{-}\right]^{0} \mathrm{t}(7)$

where $\overline{\mathrm{v}}=162.28 \mathrm{~cm}^{3} \mathrm{~mol}^{-1}, \mathrm{R}=8.3145 \mathrm{~J} \mathrm{~K}^{-1} \mathrm{~mol}^{-1}, \mathrm{r}_{0}$ is in $\mathrm{cm}, \mathrm{T}$ in $\mathrm{K},\left[\mathrm{OH}^{-}\right]$in $\mathrm{mol} \mathrm{L}^{-1}$ and $\mathrm{t}$ in $\mathrm{min}$.

It is important to mention that the rate constants obtained in this study for both reaction media are not very different from those obtained by Patiño et al. ${ }^{22}$ in the alkaline decomposition of the natrojarosite without arsenic. It seems that the arsenic contained in the natrojarosite structure studied in this work does not have a significant influence on the reaction rate (compared to a natrojarosite without arsenic). Rate experimental constant values corrected by the size factor are shown in Table 1 .

\section{Conclusions}

The alkaline decomposition of the arsenical natrojarosite is characterized by the removal of sulfate and sodium ions from the lattice and their diffusion to the solution, while a gel of iron hydroxide with adsorbed arsenate is formed. The decomposition of the arsenical natrojarosite presents an induction period and a conversion period. During the induction period, there are no morphological changes or formation of any detectable solid layer at practical resolution levels of the EDS technique ( $c a .0 .1 \mu \mathrm{m})$. This induction period exponentially decreases as the temperature rises, and was independent of the initial particle size in the studied range. The conversion period is characterized by the formation of a reaction front with an unreacted arsenical natrojarosite core and a gel halo of iron hydroxide with adsorbed arsenate. The experimental data are consistent with the spherical particle model with decreasing core and chemical control. In $\mathrm{NaOH}$ medium, the decomposition of the arsenical natrojarosite is of a fractional order of 0.7 for $\left[\mathrm{OH}^{-}\right]$concentrations ranging from $3.84 \times 10^{-3}$ to $1.08 \times 10^{-1} \mathrm{~mol} \mathrm{~L}^{-1}$, and for lower concentrations the reaction order was zero. $\mathrm{In} \mathrm{Ca}(\mathrm{OH})_{2}$ medium, the reaction order was of 1.51 for $\left[\mathrm{OH}^{-}\right]$concentrations ranging from $2.21 \times 10^{-2}$ to $6.98 \times 10^{-2} \mathrm{~mol} \mathrm{~L}^{-1}$, and for lower concentrations the reaction order was zero. The activation energy for the decomposition process in $\mathrm{NaOH}$ medium was of $57.1 \mathrm{KJ} \mathrm{mol}^{-1}$, and in $\mathrm{Ca}(\mathrm{OH})_{2}$ medium $48.1 \mathrm{KJ} \mathrm{mol}^{-1}$. The arsenic is retained in the residual solids even for times subsequent to the alkaline decomposition. The relatively high activation energy values indicate that the arsenical natrojarosite is stable under the studied conditions.

\section{Acknowledgements}

The authors would like to thank the Universidad Autónoma del Estado de Hidalgo (Mexico) for allowing us to work in the extractive metallurgy laboratory. We would also like to thank the Institute of Metallurgical Research of the UMSNH (Mexico), as well as the Facultat de Química, Universitat de Barcelona, Spain for their valuable support.

\section{References}

1. Mandal, B. K.; Suzuki, K. T.; Talanta, 2002, 58, 201.

2. Choong, T. S. Y.; Chuah, T. G.; Robiah, Y.; Gregory, K. F. L.; Azni, I.; Desalination 2007, 217, 139.

3. Norma Oficial Mexicana, Secretaría de Salud; Salud Ambiental, Agua para Uso y Consumo Humano-Limites Permisibles de Calidad y Tratamientos a que Debe Someterse el Agua para su Potabilizacion, NOM-127-SSA1-1994, México, 1994.

4. Norma Oficial Mexicana, Secretaría de Salud; Modificación NOM-127-SSA1-1994, 1999.

5. Garelick, H.; Dybowska, A.; Valsami-Jones, E.; Priest, N. D.; J. Soils Sediments 2005, 5, 182.

6. Vaclavikova, M.; Gallios, G. P.; Hredzak, S.; Jakabsky, S.; Clean. Technol. Environ. Policy 2008, 10, 89.

7. Savage, K. S.; Bird, D. K.; O’Day, P. A.; Chem. Geol. 2005, $215,473$.

8. Dutrizac, J. E.; Jambor, J. L.; Chen, T. T.; Can. Metall. Q. 1987, 26, 103.

9. Dutrizac, J. E.; Kayman, S.; Can. Mineral. 1976, 14, 151.

10. Patiño, F.; Viñals, J.; Roca, A.; Núñez, C.; Hydrometallurgy 1994, 34, 279.

11. Patiño, F.; Cruells, M.; Roca, A.; Salinas, E.; Pérez, M.; Hydrometallurgy 2003, 70, 153.

12. Salinas, E.; Roca, A.; Cruells, M.; Patiño, F.; Córdoba, D. A.; Hydrometallurgy 2001, 60, 237. 
13. Smith, A. M. L.; Dubbin, W. E.; Wright, K.; Hudson-Edwards, K. A.; Chem. Geol. 2006, 229, 344.

14. Smith, A. M. L.; Hudson-Edwards, K. A.; Dubbin, W. E.; Wright, K.; Geochim. Cosmochim. Acta 2006, 70, 608.

15. Dutrizac J. E.; Jambor J. L.; Can. Metall. Q. 1987, 26:2, 91.

16. Lide, D. R; Handbook of Chemistry and Physics, $89^{\text {th }} \mathrm{ed}$.; CRC Press: Boston, 2009, chapter 8.

17. Boudart, M.; Cinética de Procesos Químicos; $1^{\text {st }}$ ed.; Alhambra: Madrid, 1974, chapter 2.

18. Reed-Hill, R. E.; Principios de Metalurgia Física, $2^{\text {nd }}$ ed.; Continental: México, 1982, chapter 13.

19. Levenspiel, O.; Ingeniería de las Reacciones Químicas, $3^{\text {th }}$ ed.; Reverte: Barcelona, 2010, chapter 25.
20. Sohn, H. Y.; Wadsworth, M. E.; Cinética de los Procesos de la Metalurgia Extractiva; $1^{\text {st }}$ ed.; Trillas: México, 1986, chapter 1.

21. Ballester, A.; Verdeja, L. F.; Sancho, J.; Metalurgia Extractiva Fundamentos, vol. 1; $1^{\text {st }}$ ed.; Editorial Síntesis: Madrid, 2000, chapter 7.

22. Patiño, F.; Salinas, E.; Cruells, M.; Roca, A.; Hidrometallurgy 1998, 49, 323.
Submitted: March 10, 2011

Published online: August 16, 2011 